\title{
Madencilik Sektöründeki Ölümlü İş Kazalarının Analizi
}

\author{
Analysis of Fatal Work Accidents Occurring in Mining Sector
}

Özcan ÖNEY, Selçuk SAMANLI, Sümeyye ÖZMEN

\begin{abstract}
ÖZET
Madencilik sektörü, Türkiye ekonomisinin önemli bir bölümünü oluşturmakta ve ülkenin sosyoekonomik gelişiminde önemli bir rol oynamaktadır. Yeraltı ve yerüstü maden işyerleri, çalışanlar için iş sağlığı ve güvenliği açısından önemli riskler taşımaktadır. Bu işyerlerinde gerekli önlemlerin alınmaması iş kazalarına neden olabilmektedir. Ülkemizde son yıllarda madencilik sektöründe çok sayıda ölümlü iş kazalarının olması da bu sektördeki iş kazalarının internet haberleri içerisinde artan oranda yer almasına neden olmuştur. Bu çalışmada, maden işyerlerindeki ölümlü iş kazaları internet ortamında haberleştirilmiş olanlar üzerinden incelenmiştir. Sonuçta; ölümlü iş kazalarının nedenleri üzerine genel bir değerlendirme yapılmış ve alınması gereken önlemler belirtilmiștir.
\end{abstract}

Anahtar Kelimeler: Madencilik Sektörü, Ölümlü İş Kazası, İçerik Analizi

\section{ABSTRACT}

The mining sector is an important segment of the Turkey's economy and has played a significant role in the country's socioeconomic development. Both underground mining workplaces and surface mining workplaces carry significant risks in terms of occupational health and safety. Failure to take necessary precautions in these workplaces could cause work accidents. Recently, the fact that there have been many fatal work accidents in the mining sector has caused the work accidents in this sector to take place in the internet news. In this study, fatal work accidents in mine workplaces have been examined by internet news. As a result a general evaluation has been concluded on the causes of fatal work accidents and the necessary precautions to be taken have been mentioned.

Keywords: Mining Sector, Fatal Work Accident, Content Analysis

Dr. Öğr. Üyesi Özcan Öney - Uşak Üniversitesi Mühendislik Fakültesi, Maden Mühendisliği Bölümü, Uşak, Türkiye Assist. Prof. Dr. Ozcan Oney-Uşak University, Engineering Faculty, Mining Engineering Department, Uşak, Turkey Prof. Dr. Selçuk Samanlı - Uşak Üniversitesi Mühendislik Fakültesi, Maden Mühendisliği Bölümü, Uşak, Türkiye Prof. Dr. Selçuk Samanlı-Uşak University, Engineering Faculty, Mining Engineering Department, Uşak, Turkey

Dr. Sümeyye Özmen - Uşak Üniversitesi Sağlık Hizmetleri Meslek Yüksek Okulu, Sağlık Kurumları İşletmeciliği Programı, Uşak, Türkiye

Dr. Sumeyye Ozmen - Uşak University, Vocational School of Health Services, Healthcare Management Uşak, Turkey

Received/Geliş Tarihi : 07.11.2018 Accepted/Kabul Tarihi: 31.12.2018 


\section{GİRIŞ}

Madencilik sektörü; sürekli değişen ortam şartlarına göre çalışıldığından, diğer iş kollarına göre farklılıklar göstermektedir. Söz konusu sektörde arama, hazırlık, üretim, nakliyat vb. birçok aşama işs sağlığı ve güvenliği yönünden birçok riski içermektedir. Bu risklerin önlenememesi durumunda birçok iş kazası ve meslek hastalıkları ortaya çıkmaktadır [1].

Maden işyerleri, yeraltı ve yerüstü olmak üzere iki gruba ayrılmaktadır. 19.09.2013 tarih ve 28770 sayılı Resmi Gazetede yayımlanarak yürürlüğe giren Maden İşyerlerinde İş Sağlığı ve Güvenliği Yönetmeliğine göre yeraltı ve yerüstü maden işlerinin yapıldığı işyerleri, madenlerin yeraltı veya yerüstünden çıkarılması, madenlerin çıkarma amacıyla araştırılması, çıkarılan madenlerin işlenmesi hariç, satışa hazırlanması olarak ifade edilmiştir. Yeraltı işyerlerinde iş kazalarına neden olan başlıca faktörler; göçük, havalandırma, yangın ve patlama, su geliri, malzeme, nakliyat, makine ve ekipman, elektrik ve aydınlatma, diğer fiziksel tehlikeler, kimyasal ve biyolojik tehlikeler, psikososyal strestir. Yeraltı kömür ocaklarında yangın ve patlama sıklıkla karşılaşılan tehlikelerdir. Kömür tozu ve karbon monoksit, delme, patlatma ve kömür üretimi gibi aktivitelerin neticesinde ortaya çıkmaktadır. Madencilik sektöründe, psikososyal stres faktörleri de gün geçtikçe önem arz etmektedir [2].

Dünyada maden üretiminin yaklaşık üçte ikisi açı işletme yöntemiyle yapılmaktadır. Teknolojik gelişmelere bağlı olarak, açı işletmelerde kullanılan makinelerin kapasite ve verimlilik artışı birim üretim maliyetin düşmesini sağlamıştır. Sonuçta, açık ocak madenciliği yeraltı madenciliğine göre tercih edilebilir hale gelmiştir. Açık işletmelerdeki başlıca işlem aşamaları; delme, patlatma, kazıyükleme, taşıma ve dökme olarak sayılabilir [3]. Açık işlet- melerde iş kazalarına neden olan başlıca faktörler; şev kayması, taş fırlaması, iş ekipmanı kullanımı, patlayıcı madde, yüksekte çalışma, su geliri vd. olarak sayılabilir. Yerüstü maden işyerleri kapsamına, cevher hazırlama tesisleri ve madenlerin araştırılması işleri de girmektedir. Bu işyerlerinde iş kazalarına neden olan başlıca faktörler ise; yüksekte çalışma, malzeme düşmesi, iş ekipman kullanımı, elektrikle çalışma olarak sayılabilir.

Ülkemizde madencilik sektöründe yaşanan ölümlü iş kazaları, çalışanların sağlığı ve güvenliğinin giderek daha fazla olumsuz etkilendiğinin bir sonucu olarak karşımıza çıkmaktadır. Bu sektörde, işletmelerin büyük bir kısmının vardiyalı sistemde ve 24 saat çalışması, günlük değişebilen çalışma ortamının özellikleri çalışanlar açııından daha fazla riski beraberinde getirmektedir. Her yıl bu sektörde karşılaşılan iş kazaları sebebiyle birçok çalışan olumsuz etkilenmektedir. Sonuçta madencilik iş kaybı ve ölümlü iş kazasının yaşandığı bir sektördür.

İçerik analizi, metin içinde tanımlanan belirli karakterlerden sistematik ve tarafsız sonuçlar çıarmak için kullanılan bir araştırma tekniğidir [4]. Merriam-Webster’a göre içerik analizi "yayınlanmış bir materyalin bir bölümünün açık veya örtük içeriğinin, anlamını ve olası etkilerini ortaya çıkarmak maksadıyla, anahtar sembollerinin ve temalarının sınıflandırılması, tablolaştırılması ve değerlendirilmesi yoluyla analiz edilmesidir [5]. İçerik analizinde; birbirine benzeyen veriler belirli kavramlar ve temalar çerçevesinde bir araya getirilerek okuyucunun anlayabileceği bir biçimde yorumlanmaktadır [6].

Bu çalışmada madencilik sektöründe 2013-2017 yılları arasında yaşanan ölümlü iş kazalarına ilişkin verilerin internette yer alan haberleri incelenmiş ve bu veriler kullanılarak ölümlü iş kazalarının nedenleri ile sonuçlarına dair bir analiz yapılması amaçlanmıştır. Ölümlü iş kaza haberleri- 
nin yayıncı kuruluş tarafından internet ortamında verildiği haliyle içerikleri analiz edilmiştir.

\section{MATERYAL VE YÖNTEM}

Değerlendirmelerde, nitel araştırma yaklaşımlarından içerik analizi yapılmıştır. Google üzerinden "Madencilik iş sağlı̆̆ı ve güvenliği”, "Maden ölümlü iş kazası", "Kömür ölümlü iş kazası”, “Taşocağı ölümlü iş kazası”, "Mermer ölümlü iş kazası", "Yeraltı maden ölümlü iş kazası", "Yerüstü maden ölümlü iş kazası" başlıkları anahtar kelime olarak aratılarak 2013-2017 yılları arasındaki ulusal haberler taranmıştır. Sonuçta, 306 adet haber incelemeye alınmıştır. 7 sorudan oluşan içerik çözümleme yönergesi uygulanmıştır. Sorulara cevap aranabilecek bir kontrol listesi tablosu oluşturulmuştur. Oluşturulan tabloda, her bir haberin yılı, kazanın olduğu il, işletme türü (kamu, özel), kazanın olduğu yer (yerüstü veya yeraltı), madenin cinsi (kömür, metal, taş toprak, yardımcı tesis), kazanın nedeni (göçük, yüksekten düşme, elektrik, iş ekipmanı kullanımı, malzeme, taş düşmesi, patlayıcı madde, gaz vb.), kazanın sonucu (yaralanma, ölüm) incelenmiş ve değerlendirmeye alınmıştır. Sorulara yönelik elde edilen veriler kodlanmıştır. Nitel verilerin sayısallaştırılmasında sıklıktan yararlanılmıştır.

\section{BULGULAR VE TARTIŞMA}

Elde edilen verilerin istatiksel verilerle karşılaştırılmasını yapmak için ülkemizde iş kazalarına ilişkin istatistikleri düzenleyen Sosyal Güvenlik Kurumu (SGK) verileri incelenmiştir. SGK verileri incelendiğinde; madencilik sektöründe 2013-2017 yılları arasında iş kazaları sonucu ölen sigortalı sayısı toplam 711 kişidir. İnternet haberlerinin incelenmesi sonucu bu dönem içerisinde belirlenen ölen kişi sayısı ise 682 kişidir. Bu durumda madencilik sektöründe ölümlü iş kazalarının büyük bir kısmının basında yer aldığı ve güncel olarak haberleştirildiği görülmektedir. Bu dönemde, en çok ölüm 2014 yılında olmuştur ve bu yıl içerisinde 381 kişi yaşamını yitirmiştir. Bunun nedeni, Mayıs ayında Manisa ili Soma ilçesinde meydana gelmiş olan ve 301 madencinin yaşamını yitirmiş olduğu yeraltı madencilik kazasıdır. Diğer yıllar incelendiğinde ölen sigortalı sayısının 68-85 arasında değiştiği görülmektedir. Tablo 1'de Türkiye'de madencilik sektöründe iş kazasından ölen kişi sayısı 2013-2017 yılları aralığı için verilmektedir.

Tablo 1: Türkiye'de madencilik sektöründe iş kazasından ölen kişi sayısı (2013-2017) [7].

\begin{tabular}{lcc}
\hline \multirow{2}{*}{ YILLAR } & \multicolumn{2}{c}{ Ölen kişi sayısı } \\
\cline { 2 - 3 } & SGK verileri & Internet haberleri \\
\hline 2013 & 84 & 85 \\
2014 & 381 & 381 \\
2015 & 79 & 71 \\
2016 & 82 & 76 \\
2017 & 85 & 69 \\
TOPLAM & 711 & 682 \\
\hline
\end{tabular}

2013-2017 yılları arasında madencilik sektöründeki ölümü iş kazası ile ilgili haber sayısı toplam 305'dir. Söz konusu veriler Tablo 2'de verilmektedir.

Tablo 2: Türkiye'de madencilik sektöründeki ölümlü iş kazasına ilişkin haber sayısı (2013-2017)

\begin{tabular}{lc}
\hline YILLAR & internet haber sayısı \\
\hline 2013 & 73 \\
2014 & 55 \\
2015 & 68 \\
2016 & 58 \\
2017 & 52 \\
TOPLAM & 306 \\
\hline
\end{tabular}


A. Ölümlü iş kazalarının haber içeriği yönünden incelenmesi

Madencilikte, yeraltı ve yerüstünde karşılaşılan ölümlü iş kazaları hem yerel basında hem de ulusal basında detaylı olarak yer almıştır. Kazalar genellikle büyük başlıklarla ve okuyucunun dikkatini çekecek şekilde ve bazen başlığının sonuna ünlem işareti de konularak verilmektedir. Kazalar açıklayıcı bir şekilde ve genellikle yorumsuz olarak haberlerde yer almaktadır. Haberler genellikle bir resimle (kazanın olduğu yerde çekilmiş bir resim, kırık bir baret resmi, vb.) birlikte desteklenmektedir.

Ölümlü iş kazaları haberlerde yer aldığı şekliyle incelendiğinde, tüm iş kazalarında ölen kişi ile ilgili kimlik bilgilerinin açık bir şekilde verildiği ve kazanın oluş şeklinin belirtildiği görülmektedir. Kaza haberinde, öncelikle ölen kişinin adı ve soyadı, yaşı, medeni durumu (evli olup olmadığı, çocuk sayısı vb.) belirtilmekte daha sonra kazanın oluş şekli kısaca açıklanmaktadır.

Kazanın açıklamasında, maden ocağının türü (kömür işletmesi, krom işletmesi, taş ocağı, mermer ocağı vb.), kazanın olduğu yer (üretim, nakliyat vb.) ve kazanın oluş şekli (göçük, taş firlaması, malzeme, yüksekten düşme vb.) belirtilmektedir. Özellikle yeraltı taşkömürü işletmelerinde meydana gelen ölümlü iş kazalarında, kazanın olduğu kat (-360, -460 katı vb.), kazanın olduğu yer (-160/260 katındaki üretim panosunda, -260 katında galeri sü- rülmesi esnasında vb.) detaylı olarak belirtilmektedir. Kamu işletmelerinde gerçekleşen kazaların bazılarında kamu yetkililerinin kazaya ilişkin detay bilgileri verdikleri görülmüştür.

B. Ölümlü iş kazalarının işyerleri yönünden incelenmesi

Ölümlü iş kazalarının nedenlerini araştırmak amacıyla, yeraltı ve yerüstü işyerlerinde meydana gelen kaza sayısı ve bu işyerlerine ait ölümlü sigortalı sayıları incelenmiştir. 2013 yılı içerisinde 32 yeraltı ve 41 yerüstü işyerlerinde olmak üzere toplam 73 ölümlü iş kazası olmuştur. Aynı yıl içerisinde ölen sigortalı sayısı yeraltında 40 kişi ve yerüstünde 45 kişi olmak üzere 85 kişidir. 2014 yılında yerüstü işyerlerine göre yeraltı işyerlerinde daha az ölümlü kaza olmasına karşın (26 iş kazası) ölen sigortalı sayısı yerüstü işyerlerinde ölen sigortalı sayısının çok üzerindedir (348 kişi). Bunun nedeni, 2014 yll içerisinde 14 Mayıs tarihinde Soma'da meydana gelen yangın sonucu 301 madencinin öldüğü ve 27 Ekim tarihinde Karaman'da su baskını sonucu 18 kişinin hayatını kaybettiği madencilik kazalarıdır. 2013-2017 yılları arasında yeraltı işyerlerinde ölümlü iş kaza sayısı toplam 126 olup bu iş kazalarında 470 kişi yaşamını yitirmiştir. Aynı dönem içerisinde ise yerüstü işyerlerinde toplam 179 ölümlü iş kazası olmuş ve 211 kişi yaşamını yitirmiştir. Genel olarak yerüstü işyerlerinde ölümlü iş kazası sayısının yeralı işyerlerine göre fazla olduğu ancak

Tablo 3: Ölümlü kaza sayısı ve ölen işçi sayısının yeraltı ve yerüstü işyerleri itibariyle dağılımı (2013-2017)

\begin{tabular}{|c|c|c|c|c|c|c|}
\hline \multirow[t]{2}{*}{ YILLAR } & \multicolumn{3}{|c|}{ Ölümlü kaza sayısı } & \multicolumn{3}{|c|}{ Ölü Sayısı } \\
\hline & Yeralt & Yerüstü & Toplam & Yeralt & Yerüstü & Toplam \\
\hline 2013 & 32 & 41 & 73 & 40 & 45 & 85 \\
\hline 2014 & 26 & 29 & 55 & 348 & 33 & 381 \\
\hline 2015 & 30 & 38 & 68 & 31 & 40 & 71 \\
\hline 2016 & 12 & 46 & 58 & 15 & 61 & 76 \\
\hline 2017 & 26 & 26 & 52 & 36 & 33 & 69 \\
\hline TOPLAM & 126 & 180 & 306 & 470 & 212 & 682 \\
\hline
\end{tabular}


Tablo 4: Ölen işçi sayısının sektörler itibariyle dağılımı (2013-2017)

\begin{tabular}{|c|c|c|c|c|c|c|}
\hline & & Kömür & Metal & Taş ocakçılığı & $\begin{array}{l}\text { Madenciliği destekle- } \\
\text { yici hizmet faaliyetleri }\end{array}$ & Toplam \\
\hline & Yeralt & 35 & 5 & 0 & 0 & 40 \\
\hline \multirow[t]{3}{*}{2013} & Yerüstü & 5 & 9 & 27 & 4 & 45 \\
\hline & Toplam & 40 & 14 & 27 & 4 & 85 \\
\hline & Yeralt & 343 & 5 & 0 & 0 & 348 \\
\hline \multirow[t]{3}{*}{2014} & Yerüstü & 8 & 2 & 22 & 1 & 33 \\
\hline & Toplam & 351 & 7 & 22 & 1 & 381 \\
\hline & Yeralt & 24 & 6 & 1 & 0 & 31 \\
\hline \multirow[t]{3}{*}{2015} & Yerüstü & 3 & 7 & 30 & 0 & 40 \\
\hline & Toplam & 27 & 13 & 31 & 0 & 71 \\
\hline & Yeralt & 11 & 4 & 0 & 0 & 15 \\
\hline \multirow[t]{3}{*}{2016} & Yerüstü & 3 & 21 & 37 & 0 & 61 \\
\hline & Toplam & 14 & 25 & 37 & 0 & 76 \\
\hline & Yeralt & 28 & 8 & 0 & 0 & 36 \\
\hline \multirow[t]{3}{*}{2017} & Yerüstü & 13 & 3 & 17 & 0 & 33 \\
\hline & Toplam & 41 & 11 & 17 & 0 & 69 \\
\hline & Yeralt & 441 & 28 & 1 & 0 & 470 \\
\hline \multirow[t]{2}{*}{ TOPLAM } & Yerüstü & 32 & 42 & 133 & 5 & 212 \\
\hline & Genel Toplam & 473 & 70 & 134 & 5 & 682 \\
\hline
\end{tabular}

yeraltı işyerlerinde sayısal olarak daha az ölümlü iş kazası olmasına karşılık yüksek oranda ölümler gerçekleştiği sonucu çıkmaktadır. Aşağıda sunulan, Tablo 3'de ölümlü kaza sayısı ve ölen işçi sayısının yeraltı ve yerüstü işyerleri itibariyle dağılımı 2013-2017 yılları aralığı için verilmiştir.

2013-2017 yılları arasında madencilik iş kolunda iş kazalarından ölen işçi sayılarının sektörler itibariyle dağılımı Tablo 4'de verilmektedir.

$\mathrm{Bu}$ dönem içerisinde kömür madenciliğinde 473 kişi $(\% 69,35)$ taş ocakçılığında 134 kişi $(\% 19,65)$, metal madenciliğinde 70 kişi $(\% 10,26)$ ve madenciliği destekleyici hizmet faaliyetleri (NACE 09 kodlu) $(\% 0,73)$ çalışmaları esnasında oluşan iş kazaları nedeniyle yaşamlarını kaybetmişlerdir. İş kazasından ölen kişi sayısı en çok kömür madenciliğinde olmuştur. Bu sektörde gerçekleşen ölümlü iş kazaları, Zonguldak ve Manisa (Soma) illeri başta olmak üzere 20 'den fazla ilde gerçekleşmiş ve toplamda 440 kişi hayatını kaybetmiştir.

1. Yeraltı işyerlerinde meydana gelen ölümlü iş kazalarının nedenleri

Yeraltı işyerlerinde meydana gelen ölümlü iş kazalarının hemen hemen tamamının $(\% 99,77)$ kömür $(\% 93,82)$ ve metal madenciliğinde (\% 5,95) olduğu görülmektedir. 2013-2017 yılları arasında toplam 470 kişi yeraltı işyerlerinde meydana gelen iş kazaları sonucu yaşamını yitirmiş olup yeraltı kömür madenciliği özelinde ise ölen kişi sayısı 441'dir. Şekil 1'de Türkiye'de kömür üretimi yapılan başlıca iller verilmektedir.

Bilindiği üzere ülkemizde en önemli kömür madenciliği, taşkömürü ve linyit madenciliği olarak iki gruba ayrıl- 
.

Şekil 1: Türkiye'de kömür üretimi yapılan başlıca iller [8]

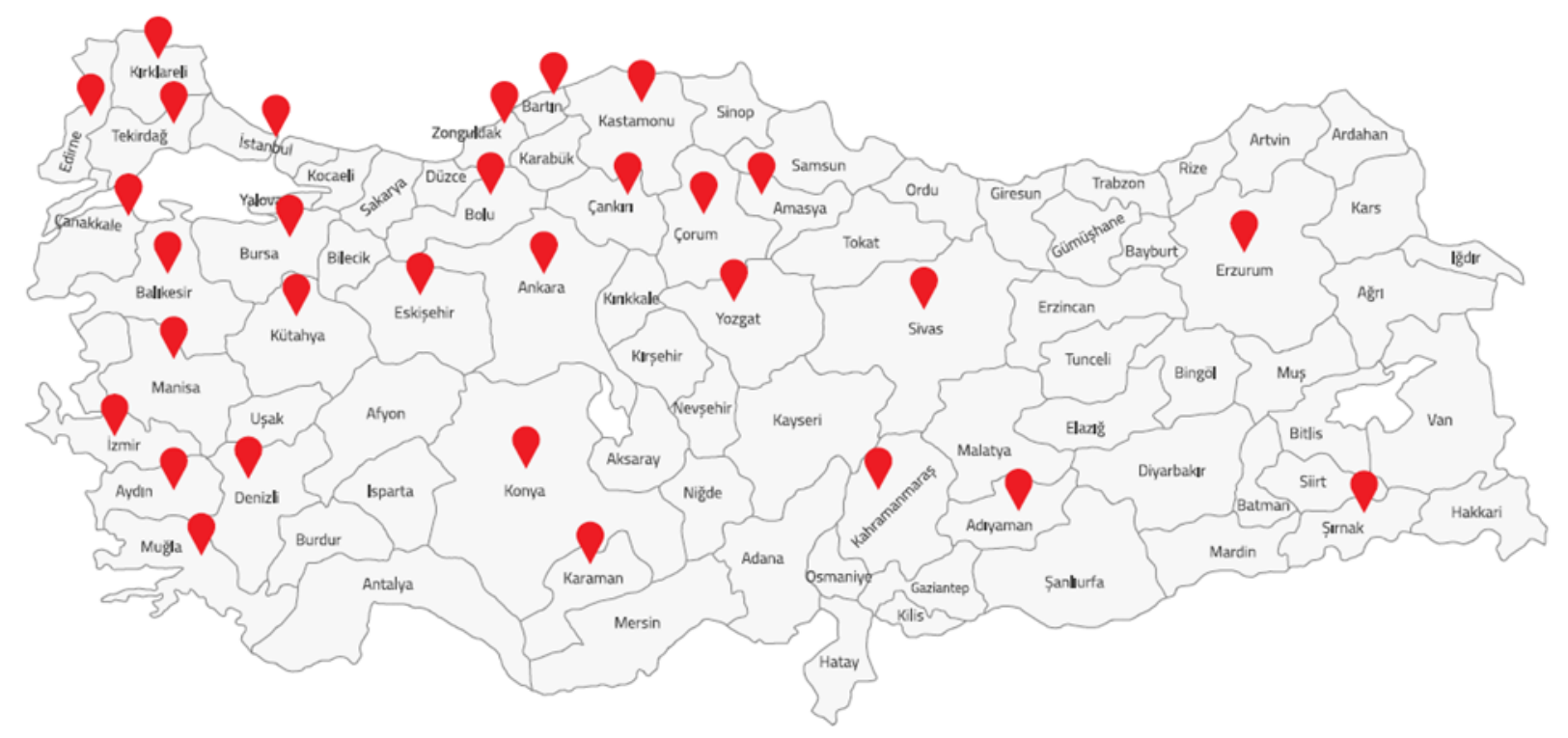

mıştır. Ülkemizde taşkömürü rezervleri, Zonguldak havzasında bulunmaktadır. Taşkömürü üretimi uzun yıllar devlet tarafından gerçekleştirilmiştir. 2004 yılından itibaren ise Maden kanununda yapılan değişiklikle devlet tarafından işletilmeyen ve atıl durumdaki kömür rezervleri rödevans yolu ile üçüncü şahıslara verilmektedir. Halen havzada kamu ve özel sektör tarafından taşkömürü madenciliği faaliyetleri sürdürülmektedir [9]. Üretimin tamamı yeraltı işletmeciliği ile gerçekleştirilmektedir. Linyit üretimleri ise kamu ve özel sektör tarafından birçok ilde yapılmaktadır. Bilhassa Ege, Trakya ve İç Anadolu Bölgeleri'nde linyit madenciliği yaygın olarak yürütülmektedir. Linyit madenciliğinde, açık ve yeraltı işletmeciliği olmak üzere iki temel yöntem uygulanmaktadır. Yüzeye yakın kömür oluşumları açık işletme yöntemi ile üretilmekte iken derin kömür damarlarında ise yeraltı işletme yöntemi tercih edilmektedir.

Kömür madenciliğinde, yeraltı işyerlerinde gerçekleşen ölümlü iş kazalarının en çok Zonguldak ve Manisa (Soma) illerinde olduğu görülmektedir. Soma ve Ermenek'teki ölümlü iş kazaları hariç tutulduğunda ölümlü iş kazalarının başlıca nedeni göçük olmaktadır. Bilindiği üzere yeraltında üretim gerçekleştirmek amacıyla çeşitli kesit ve boyutlarda galeriler açılmakta ve bu boşluklar uygun şekilde tahkim edilmektedir. Tahkimat sistemlerinin iyi uygulanmadığı durumlarda "göçük” denilen kazalar meydana gelmektedir [10].

Göçük sonucu meydana gelen ölümlü iş kazalarının genellikle taşkömürü madenciliğinde olduğu görülmektedir. Bunun nedeni, Zonguldak havasının yapısı gereği mekanize üretim yöntemlerinin uygulanamaması, özellikle üretim yerlerinde emek yoğun çalışma yapılması sonucu ağaç tahkimatın uygulanması olarak değerlendirilmektedir. Özellikle küçük işletmelerde yetersiz tahkimat ve uygun olmayan üretim yöntemlerinin kullanılması da göçük olaylarının sık yaşanmasının başlıca nedenlerindendir. Ayrıca, kaçak kömür ocaklarında da sıklıkla ölümlü iş kazaları olmaktadır.

Maden İssyerlerinde İş Sağlığı ve Güvenliği Yönetmeliğinde tahkimat ile ilgili maddeler bulunmakta olup, yaşanan ölümlü kaza olayları ilave tedbirler alınmasını zorunlu kılmaktadır. Özellikle yeraltı kömür madenciliğinin emek yoğun yapıldığı yerlerde gerek tahkimat açısından gerekse 
de kazı işleri açısından iş sağlığı ve güvenliği ile ilgili daha detaylı hükümlere yer verilmesi zorunludur.

Yeraltı kömür madenciliğinde, ölümlü iş kazalarının olmasında önemli bir diğer risk faktörü de havalandırma sistemlerinin yeterli olmamasıdır. Yeraltı hazırlık ve üretim çalışmalarında ortama gönderilen temiz hava; cevher, kömür damarı ve çevre kayaçları içerisinde bulunan zararlı gazlar, cevher ve kömürün oksidasyonu, ocak tozları vd. nedenlerle kirlenmektedir. Ayrıca, ocak havasındaki oksijen miktarı, işçilerin solunumu, patlayıcı madde kullanımı ve makinelerin çalışması sonucunda azalmaktadır. Derin ocaklardaki yüksek sıcaklık ve nem de çalışma koşullarını olumsuz yönde etkilemektedir. Ocak havası içerisindeki karbon monoksit, hidrojen sülfür, kükürt dioksit vb. zehirli gazlar, metan vb. patlayıcı gazlar, karbon dioksit vb. boğucu gazlar ve patlayıcı özellik gösteren kömür tozu yeraltında tehlikeli çalışma ortamı oluştururlar. Bu olumsuzlukları gidermek ve gerekli oksijeni sağlamak amacıyla yeterli miktarda temiz havanın yeraltına gönderilmesi zorunludur. Bunun için yönetmeliğe göre uygun sistemlerin kurulması ve belirlenen istasyonlarda belirli periyodlarda hava ölçümlerinin yapılarak ocak havasının sürekli olarak kontrol altında tutulması sağlanmalıdır [11].

Denetimlerde özellikle küçük işletmelerde havalandırma kontrolünün sıklıkla yapılması gereklidir. Yeraltı kömür işyerlerinde yaşanan ölümlü iş kazalarının nedenleri arasında vagon devrilmesi, vagonların katardan boşalması, iş ekipmanının hatalı kullanımı, malzeme düşmesi ve elektrik çarpması da sayılabilir.

Yeraltı ölümlü iş kazalarının olduğu bir diğer sektör de metal sektörüdür. Bu sektörde, krom ve bakır başta olmak üzere kurşun, demir, altın, antimuan ve çinko madenlerinin üretimleri esnasında ölümlü iş kazaları yaşanmıştır. İş kazalarının nedenleri arasında, göçük, gaz zehirlenmesi ve taş düşmesi öncelikli nedenler olarak sayılabilir.

2. Yerüstü işyerlerinde meydana gelen ölümlü iş kazalarının nedenleri

Yerüstü işyerlerinde meydana gelen ölümlü iş kazalarının büyük bir kısmının $(\% 62,56)$ diğer madencilik ve taş ocakçılığında olduğu görülmektedir. Bunu, \%19,91 ile metal madenciliği ve \%15,17 ile kömür madenciliği izlemektedir. Diğer madencilik ve taş ocakçllı̆̆ında yaşanan ölümlü kazaların büyük bir çoğunluğu ise mermer üretimi ve işlenmesi faaliyetleri esnasında meydana gelmektedir. Dünyanın en zengin doğal taş oluşumlarının bulunduğu Alp kuşağında yer alan Türkiye çok çeşitli ve büyük miktarda mermer rezervine sahiptir. Söz konusu rezervler özellikle Diyarbakır, Elazığ, Afyon, Bilecik, Denizli, Balıkesir, Muğla ve Amasya illerinde yoğunlaşmıştır. Son dönemde yapılan yatırımlarla birlikte Türkiye, dünya doğal taş üretiminde lider yedi üretici ülkeden birisi konumuna gelmiştir [10]. Mermer işletmeciliği, gerek ocak gerekse de işleme süreçlerinde işgücü ve teknolojinin ortaklaşa kullanıldığı ağır çalışma şartlarının olduğu riskli bir sektördür. Ülkemizde, birçok yerde mermer işleme tesislerine rastlanmakta ve gün geçtikçe bu tesislerin sayıları artmaktadır. Söz konusu işletmelerde çok çeşitli makineler kullanılmaktadır. Kullanılan makine ve ekipmanların artması ile alınacak güvenlik önlemleri de çeşitlenerek artmaktadır [12,13]. Mermer işyerlerindeki ölümlü iş kazlarının nedenleri arasında blok düşmesi, iş ekipmanı kullanımı, yüksekten düşme, patlayıcı madde kullanımı ve malzeme çarpması sayılabilir.

Türkiye'de, mermer ocak işletmeciliği çoğunlukla açık işletme yöntemi ile yapılmaktadır. Bu yöntemde ortalama basamak yükseklikleri 6-10 metre olarak oluşturulmakta ve kademeler farklı boyutlarda kesilerek üretim yapılmaktadır. Basamakların ilk ağız açılması işlemi sırasında, serbest yüzey oluşturmak amacıyla üçgen kesim uygulaması yapılmaktadır. Bu işlem yerine, patlayıcı madde kullanılması iş 
kazalarına neden olmaktadır. Basamaklardan büyük dilimlerin kesilmesi ve kesilen bu dilimlerden daha küçük küçük dilimler oluşturulması işlemlerinde çoğunlukla tel kesme makineleri kullanılmaktadır. Tel kesme makineleri mermer bloğu içerisinde önceden açılmış delikler içerisinde belirli bir hızla hareket etmesi sonucunda blokları kesen özel makinelerdir. Telin çalışma anında kopması durumunda serbest kalan tel geniş bir alanda hareket etmekte, ayrica tel üzerindeki bulunan elmaslar, bilezikler, sıkma parçaları ve yaylar işletme alanına yayılarak temas ettiği yer ve kişilere önemli zarar ve hasar vermektedir [14]. Mermer işletmelerinde kesilen büyük blokların devrilmeleri, sayalanmaları ve taşınmalarında kullanılan ağır iş makineleri ve kamyonlar potansiyel iş kazası nedenleridir [14].

Türkiye'de çok çeşitli nitelik ve özellikte doğal taş çeşidine sahiptir. Başlıca doğal taş rezervleri Anadolu ve Trakya bölgeleri boyunca geniş bir alana yayılmıştır. Söz konusu rezervler; Ege Bölgesinde \%32, Marmara Bölgesinde \% 26, İç Anadolu Bölgesinde \%11, Doğu Anadolu Güneydoğu Anadolu, Karadeniz ve Akdeniz Bölgelerinde ise \%31 olarak dağılmaktadır. Sektörde yaklaşık olarak 1.500 adet doğal taş ocağı, fabrika ölçeğinde faaliyet gösteren 2.000 kadar tesis, orta ve küçük ölçekli 9.000 atölye yer almaktadır. Türkiye'de yıllık doğal taş üretimi yaklaşık 11,5 milyon tondur. Mermer işleme tesislerinin toplam plaka üretim kapasitesi ise 6,5 milyon $\mathrm{m} 2$ civarındadır $[15,16]$. Doğal taş ocakçılığında ise, iş makinesinin devrilmesi, şev kayması, malzeme düşmesi, dinamit kullanımı, ekipmanın hatalı kullanımı, yüksekten düşme, kaya parçasının düşmesi vb. nedenlere ölümlü iş kazaları gerçekleşmiştir.

Kömür sektöründe yerüstünde gerçekleşen ölümlü iş kazalarının nedenleri arasında yüksekten düşme, kamyon altında ezilme, ekipman çarpması, şev kayması, banda sıkışma sayılabilir.

\section{SONUÇ}

Madencilik sektöründe yaşanan ölümlü iş kazaları, gelişen iletişim teknolojisi ile toplumun her kesimi tarafından kolaylıkla ulaşılabilir ve takip edilebilir olmuştur. İş kazalarının önlenmesi ve çalışanların iş sağlığı ve güvenliği için gerekli tedbirlerin özenle alınması gereklidir. Bu kapsamda; yerüstü ve yeraltı madencilik faaliyetleri detaylı olarak analiz edilmeli, iş kazalarının hangi çalışmalarda daha sık görüldüğü, hangi makinelerde ve hangi sebeplerden gerçekleştiği araştırılmalı, bunları önlemek için düzenleyici tedbirlerin neler olması gerektiği üzerine odaklanılmalıdır. Özellikle kömür madenciliği, mermer, taş ocakçıl1ğ1 ve krom madenciliği ile ilgili iş sağlığı ve güvenliği ile ilgili denetimler arttırılmalı ve gerekli yasal düzenlemeler yapılmalıdır. Bu alanlarda ortaya çıkacak iş kazalarının ve ölümlerin azaltılması sonucunda; çalışanlar, işverenler ve ülkemiz açısından daha sağlıklı bir çalışma ortamı oluşturulacak ve böylece madencilik sektörünün gelişmesine önemli oranda katkı sağlanacaktır.

\section{KAYNAKLAR}

[1] Tozman, B., (2010). Türkiye Madencilik Sektöründe İş Kazalarının İstatistiksel Analizi, Yüksek Lisans Tezi, Eskişehir Osmangazi Üniversitesi, Fen Bilimleri Enstitüsü.

[2] Çalışma ve Sosyal Güvenlik Eğitim ve Araştırma Merkezi (ÇASGEM), (2016). Madencilik Sektöründe İş Kazaları.

[3] T.C. Çalıșma Ve Sosyal Güvenlik Bakanlığ İș Teftiş Kurulu Başkanlığı, (2011). Yeraltı Ve Yerüstü Maden İşletmelerinde İş Sağlığı Ve Güvenliği Rehberi, Yayın No: 43, Ankara.

[4] Stone P. J,, Dunphy D. C., Marshall S. S., Ogilvie D.M., (1966). The General Inquirer: A Computer Approach to Content Analysis, The M.I.T. Press, Massachusetts.

[5] Özden, M.Y., Durdu, L., (2016). Nitel Araştırma Yöntemleri, Anı Yayıncılık, Ankara,

[6] Yıldırım, A., Şimşek H., (2013).Sosyal Bilimlerde Nitel Araştırma Yöntemleri, Seçkin Yayıncılık, 9. 
Baskı, Ankara.

[7] T.C. Sosyal Güvenlik Kurumu, Erişim Tarihi: 4.11.2018, http://www.sgk.gov.tr/wps/portal/sgk/tr/ kurumsal/istatistik/sgk_istatistik_yilliklari

[8] T.C. Enerji Ve Tabii Kaynaklar Bakanlığı, Türkiye Kömür İşletmeleri Kurumu (2016). Kömür Sektör Raporu. Erişim Tarihi: 12.11.2017.

http://www.enerji.gov.tr/File/?path=ROOT\%2F1\% 2FDocuments\%2FSekt\%C3\%B6r\%20Raporu\% 2FSEKT\%C3\%96R\%20RAPORU\%202015\% 2030.06.2015\%20SON.pdf

[9] T.C. Enerji Ve Tabii Kaynaklar Bakanlığı, Türkiye Taşkömürü Kurumu (2016). Taşkömürü sektör raporu, Erişim Tarihi: 02.03.2018

http://www.taskomuru.gov.tr/file/duyuru/ TTKGM_Sektor_Raporu_2016.PDF

[10] Tatar, Ç., İpekoğlu, Ü., Aksoy, O., Mallı, T., (2011). Madenciliğe Giriş, Dokuz Eylül Üniversitesi, Mühendislik Fakültesi Yayınları No:319, İzmir

[11] İş Sağlığı ve Güvenliği Genel Müdürlüğü (İSGGM), KOBİ’ler için İş Sağlığı ve Güvenliği Yönetim Rehberi: Risk Değerlendirmesi, İSG Performans İzleme ve Sağlık Tehlikeleri, Maden Sektörü: Kömür

[12] Bilger, E., Demirci, S., (2017). Mermer İşleme Tesislerinde İş Sağlığı ve Güvenliği, Uluslararası Maden İşletmelerinde İşçi Sağlığı ve İş Güvenliği Sempozyumu, 02 - 03 Kasım, Adana, 825-833.

[13] Eleren, A., Ersoy, M., (2011). Mermer Ocaklarında Elmas Tel ve Kollu Kesiciyle Kesme Teknolojilerinin İş Güvenliği Bakımından Karşılaştırılmasında Hata Türü Etki Analizi Yönteminin Uygulanması. Türk Bilim Araştırma Vakfı. 4, 11, 9-19.

[14] Gümüş, A., Akkoyun, Ö., (2018). Mermer Ocak İşletmeciliğinde Sık Karşılaşılan İs Kazaları Üzerine Bir İnceleme,

http://www.dicle.edu.tr/a/oakkoyun/papers/ mermer_is_kaza_ocak.pdf

[15] T.C. Ekonomi Bakanlığı, Doğaltaş Sektör Raporu, (2017). Erişim Tarihi: 11.08.2017.

http://www.enerji.gov.tr/tr-TR/Sayfalar/DogalTaslar,

[16] Hatipoğlu, C., (2016) . Doğaltaş Sektöründe Faaliyet Gösteren Bir İşletmenin Üretim Ve Planlama Sürecinin İncelenmesi, Akademik Bakış Dergisi, 53, 186198. 